\title{
特 集＼cjkstart胃癌：診断と治療の進歩
}

\section{トピックス}

\section{I. 疫学・原因 · 遺伝子異常 \\ 1. 胃癌の疫学と今後の動向}

井上真奈美

要旨

わが国の胃癌は，䍜患率，死亡率とも，諸外国と同様に一貫した低下傾向にあるが，低下の開始時期 が欧米先進国と比較して遅く、現在なお高率である。それでも最近は，トップだった䍜患や死亡順位が 他癌と入れ替わるなど, 样相が変貌しつつある.今後, 急速な高齢化に伴いしばらく患者数自体は低下 しないが，長期的にみれば，わが国の胃癌は大きく減少していくと予想される.

〔日内会誌 $94 ： 3 \sim 10,2005$ ]

Key words：胃癌, 疫学, 動向

\section{1.世界における胃癌の動向}

国際がん研究機関 (International Agency for Research on Cancer : IARC)による 2000 年の推 計”によると,世界の胃癌罹患数は, 肺癌, 乳癌, 大腸癌に続き第 4 位 $(8.7 \%)$ ，また，胃癌死亡数 は肺癌に続いて第 2 位 $(10.4 \%)$ にランクされ， 世界的に見て主要ながんの一つである。そして， 世界の胃癌羅患数の $54 \%$ が東アジア地域から起 こっており，国別には，世界の胃癌の $38 \%$ は中 国，13\% が日本からの発生である(図 1)，全体 からみれば，胃癌は罹患，死亡とも，60～70\% が発展途上国で起こっていると推測されている.

患者数そのものは，人口規模や年歯令構成，特 に，がんになりやすい高跉者層の影響を受ける が，これらの影響を取り除いた年齢調整罹患率 で見てみると（図 2)，男性では韓国に次いで日 本が第 2 位，女性では日本が第 1 位で韓国がそ

いのうえ まなみ：国立がんセンターがん予防・検診

研究センター予防研究部
れに次いで抢り，日本は韓国と並び，胃癌の最 も高率な国といえる。全体としては，東アジア の他，東欧，南米諸国で胃癌が高率に見られ， 反対に，北米，豪州，北欧諸国を中心とした先 進国や, 東南アジア及び南アジアは低率である。

世界各国の胃癌は，罹患，死亡ともにほとん どの国で一貫した低下傾向を示している．現在 は胃癌がまれながんと位置づけられている米国 や北欧諸国などでも，かつては死因の上位を占 めていた。しかしながら，日本の胃癌の特徽は， 罹患率，死亡率ともに諸外国と同様に低下して いるにもかかわらず，低下の開始時期が欧米先 進国と比較して遅く，現在なお高率となってい ることである。

\section{2.わが国における胃癌の動向}

わが国では, 胃癌はかつて,がん死亡数のトッ プであったが，近年はその様相も変貌しつつあ る。全体としては, 1999 年以降胃癌死亡は肺癌 に抜かれて第 2 位となっており，2003 年にはが 


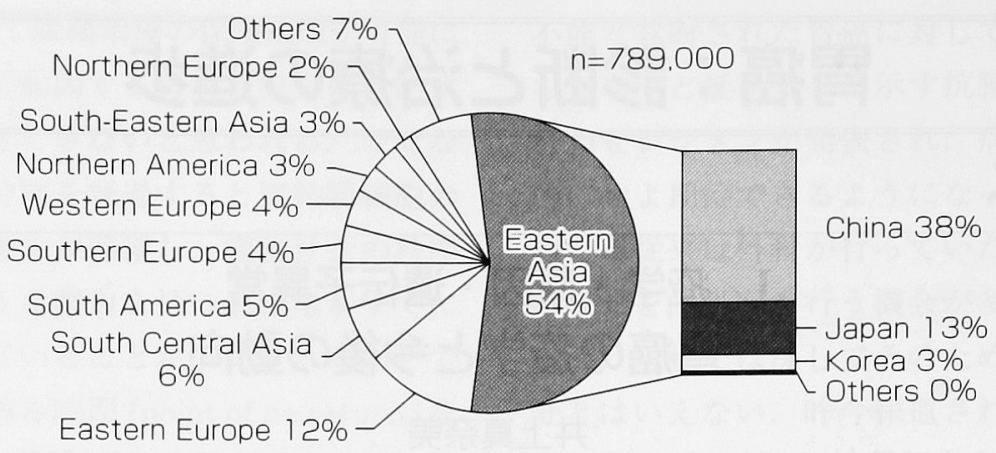

図 1.世界の胃癌の分布 (2000 年)(文献 1 より)
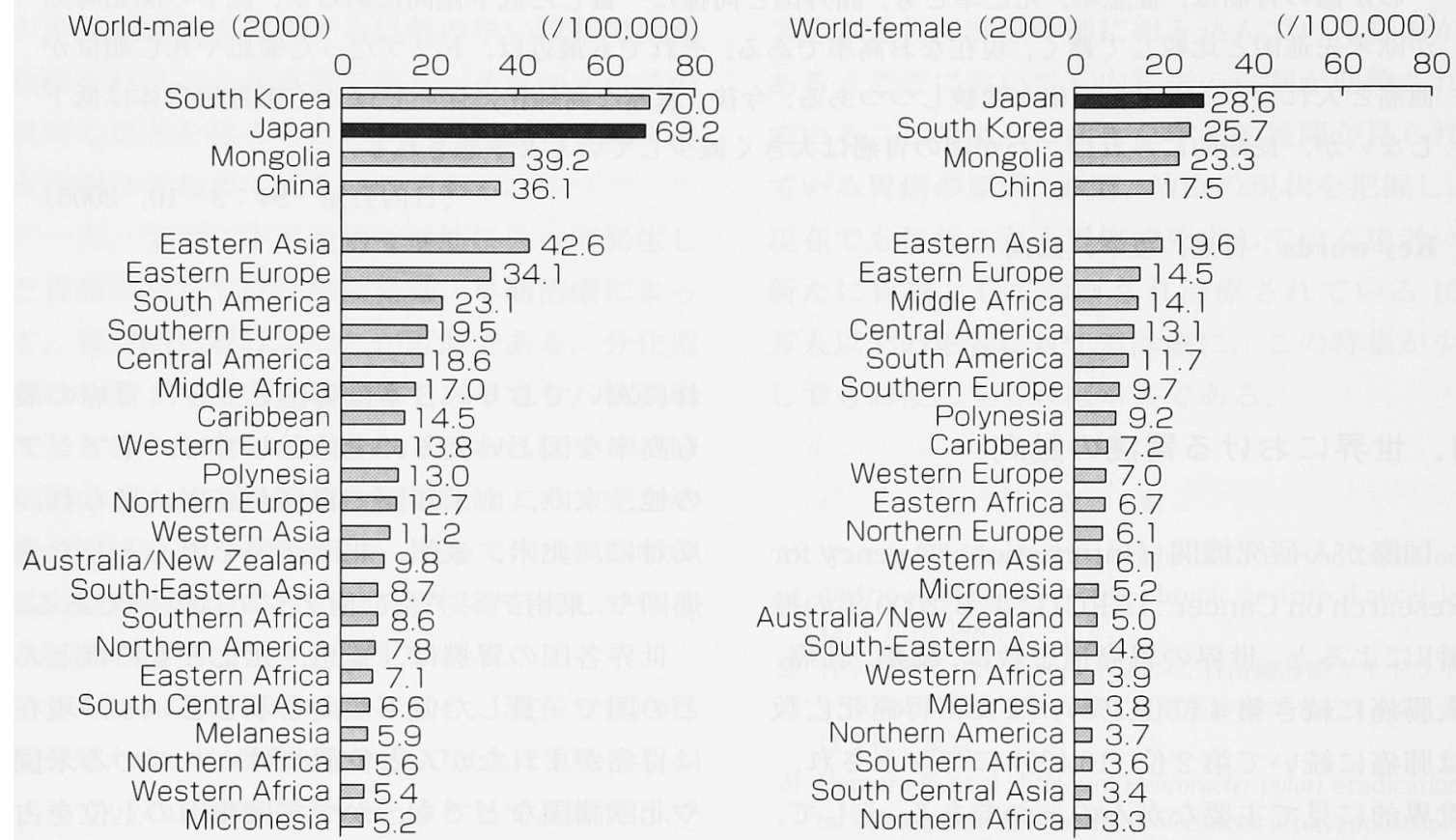

図 2. 世界の胃癌の年齢調整罹患率一世界人口による年齢調整一（2000 年）(文献 1 より)

ん死亡全体の $16 \%$, 約 5 万人が胃癌で死亡して いる2). 男女別に見ると, 男性では肺癌に次いで 第 2 位, 女性では依然 1 位を占めている (図 3). しかし，女性では，2003 年には結腸癌と直腸癌 をあわせた大腸癌には追い抜かれていることも 事実である。一方，がんの䍜患についてみると， 胃癌が最も多く, 1999 年の全国推計では, 約 10 万 4 千人（がん全体の $20 \%$ ）の胃癌が新たに発 生している ${ }^{3)}$ ．男女別に見ると，男性では第 1 位,
女性では，1994 年に乳癌に抜かれ，現在は第 2 位となっている $\left(\right.$ 図 4) ${ }^{3)}$.

胃癌年齢調整率は, 近年では, 罹患, 死亡と も，一貫した減少傾向にある。一方，率ではな く数に焦点を当ててみると, 死亡数は男女とも 横ばいで明確な減少傾向は見られていない。䍜 患数は女性では近年横ばいになってきたものの, 男性ではむしろ増加している（図 5)．わが国に おける胃癌死亡の推移を年齢群別に見てみると, 


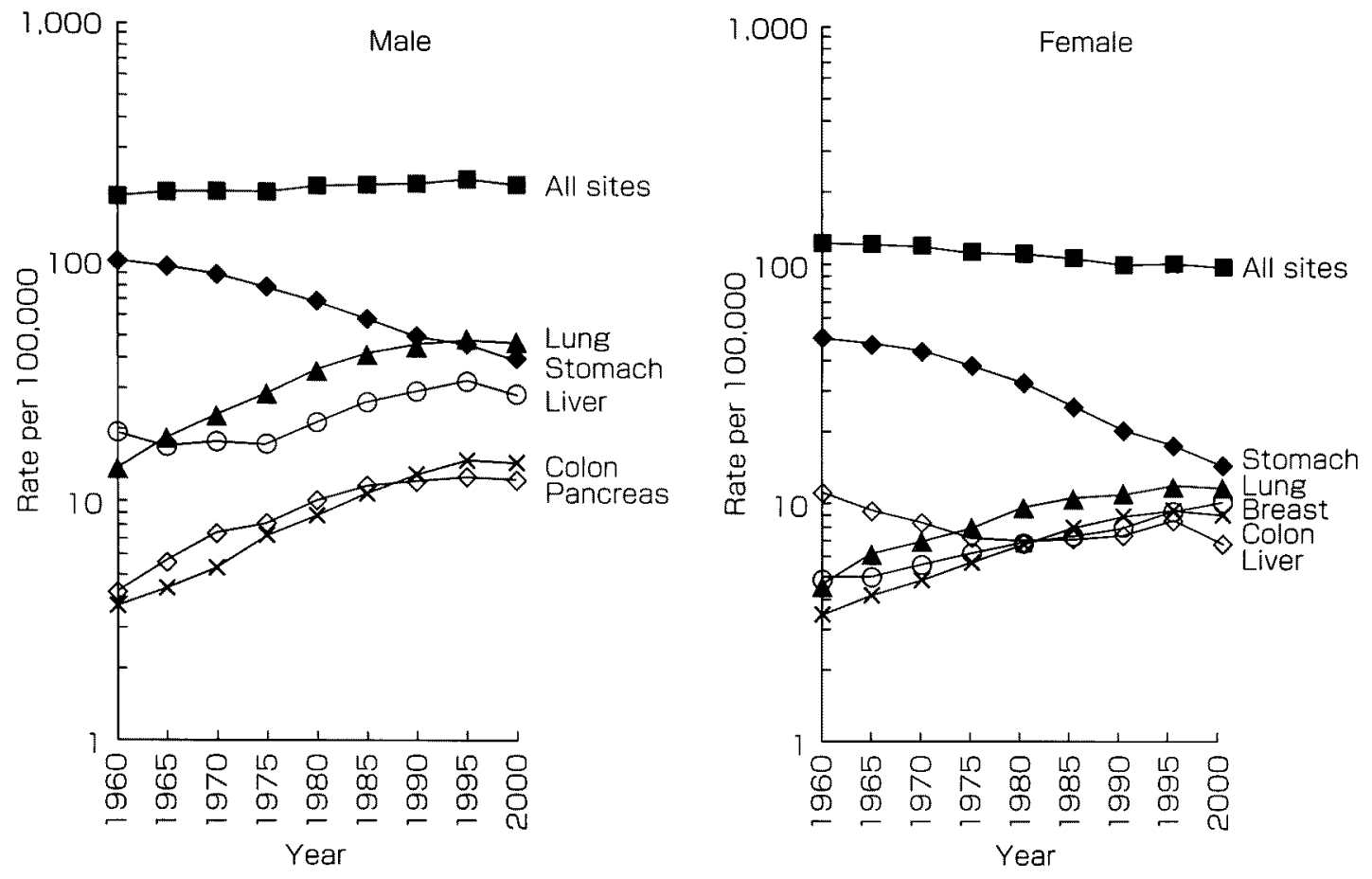

図 3. 日本人のがん死亡率の年次推移-1985 年日本人モデル人口による年龄調整率（文献 4 より）
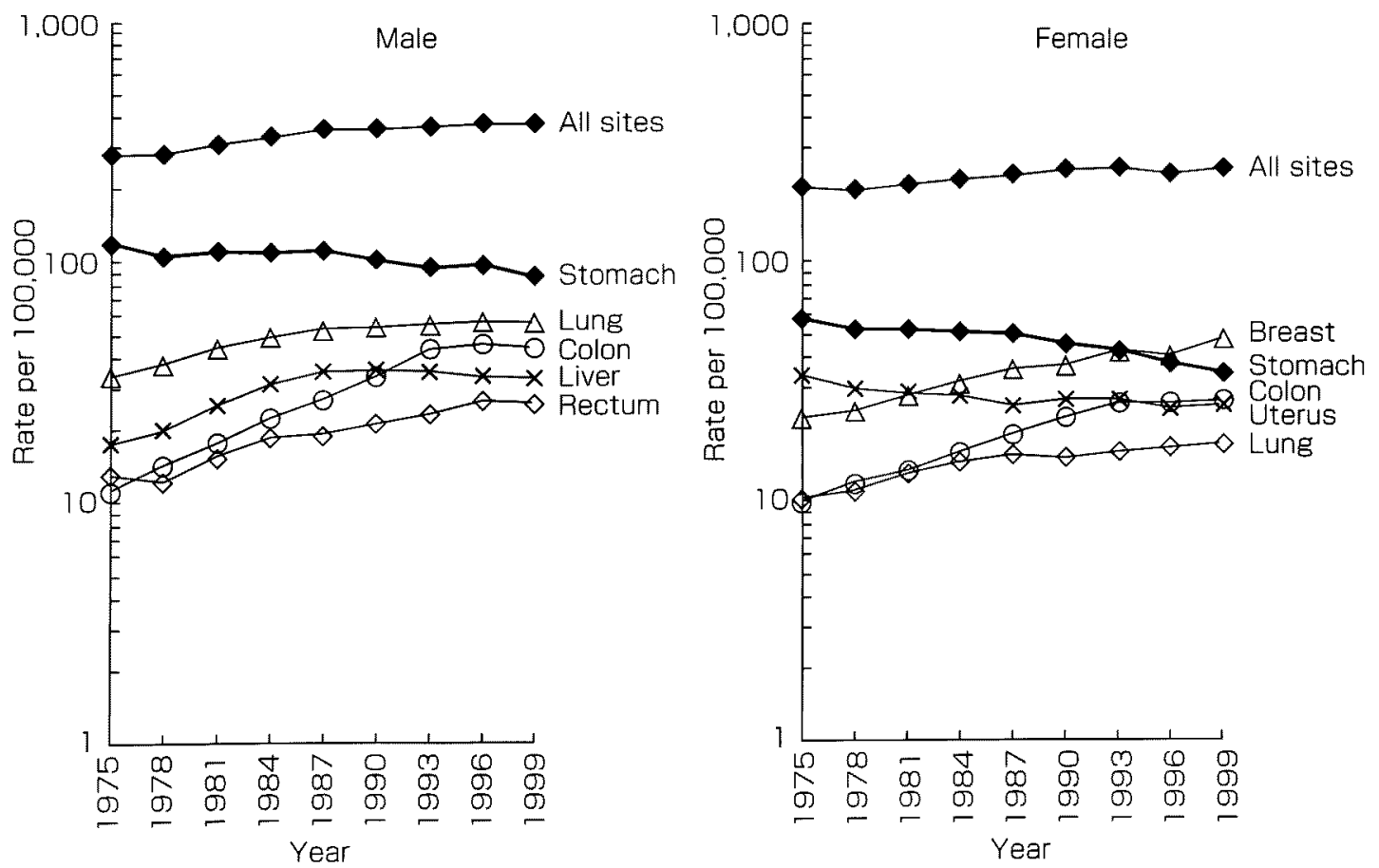

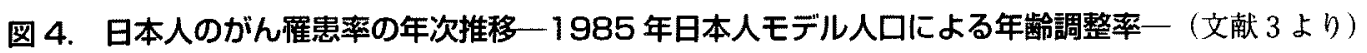



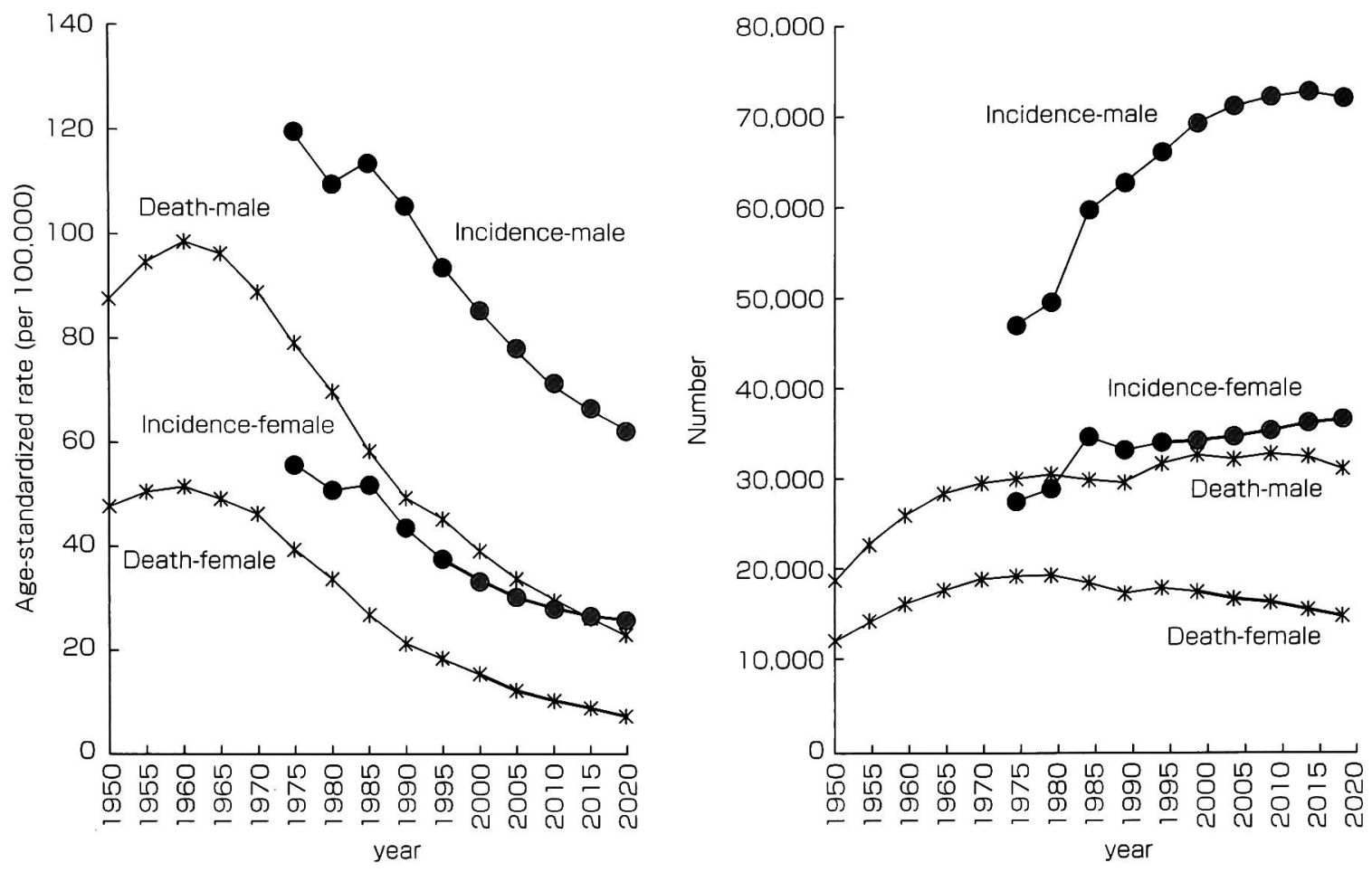

図 5. 日本における胃癌の罹患及び死亡の年次推移及び将来予測（文献 3，4ょり）

Male

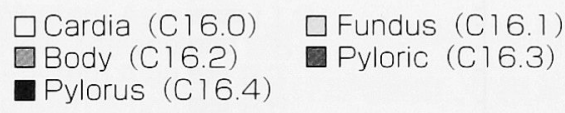

Hiroshima-Japan

Miyagi-Japan

Nagasaki-Japan

Osaka-Japan

Saga-Japan

Yamagata-Japan

Seoul-Korea

LA-USA Japanese

Romagna-Italy

Slovenia

The Netherlands

Walsaw-Poland

Sweden

Yorkshire-UK

SEER-USA Whites

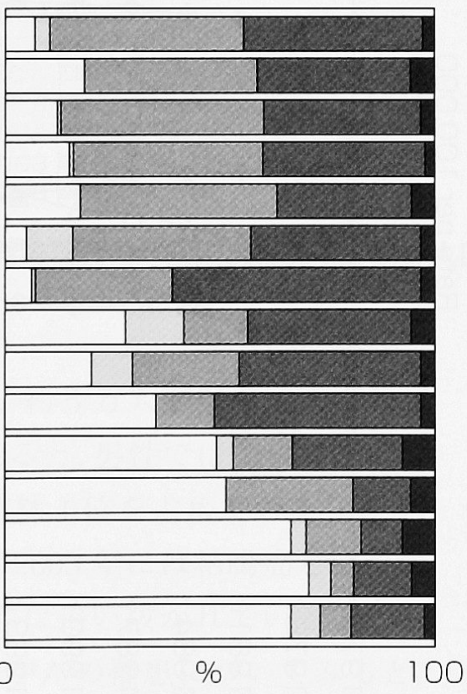

Female

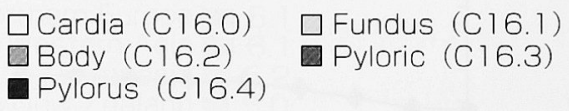

Hiroshima-Japan Miyagi-Japan

Nagasaki-Japan

Osaka-Japan

Saga-Japan

Yamagata-Japan

Seoul-Korea

LA-USA Japanese

Romagna-Italy

Slovenia

The Netherlands

Walsaw-Poland

Sweden

Yorkshire-UK

SEER-USA Whites

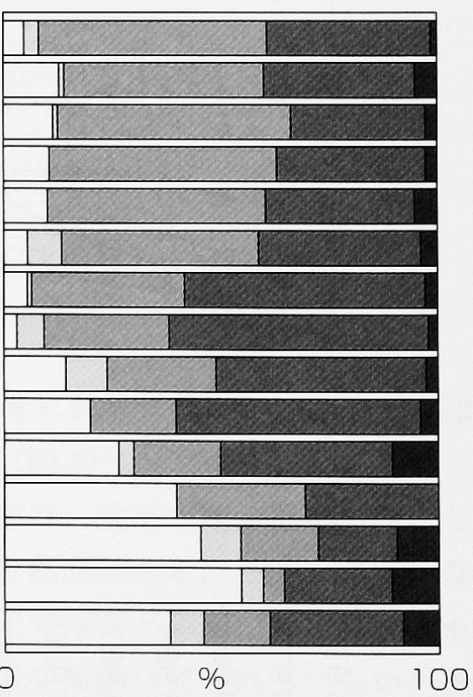

図 6. 胃癌の亜部位の分布, 1993〜 1997 (文献 5 より) 

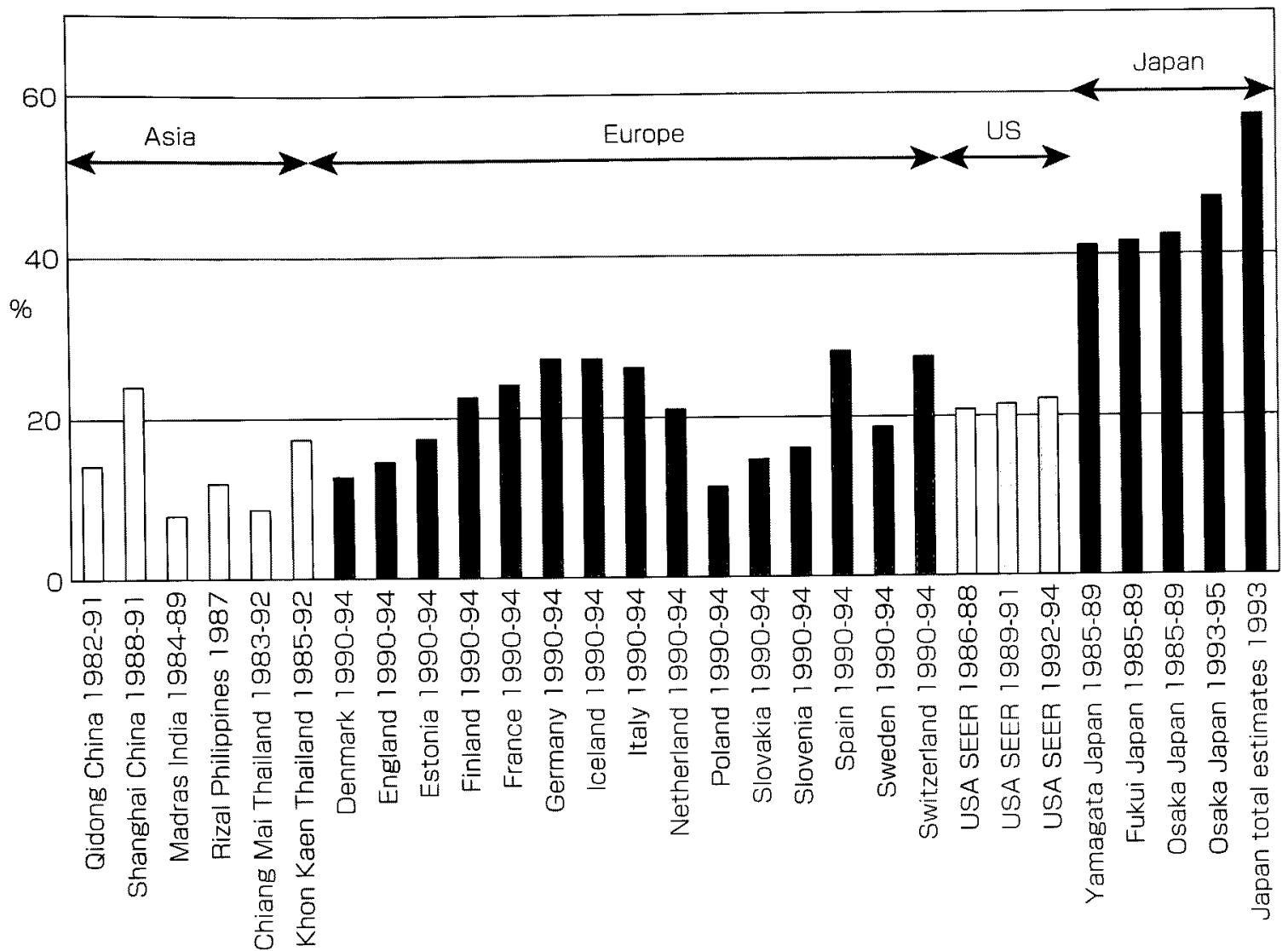

図 7. 5 年相対生存率（\%）の国際比較（文献 6 9 上り）

若年者ほど減少が顕著であり, 85 歳以上の超高 齢者層でのみ死亡率の増加傾向が見られ，篗患 についても死亡ほど明確ではないが，同様の傾 向が見られている4 . また, 平均死亡年齢も年々 上昇し，2000年には男性で 71 歳，女性で 74 歳となり, 胃癌死亡の高齢化が起こっている4.

\section{3. わが国の胃癌の特性}

世界的にみて，わが国の胃癌にはいくつかの 特性がある。

まず，わが国の胃癌は，欧米諸国と比較して， より遠位部に発生する割合が高い。これは, 病 院の症例群を対象とした学術報告のみならず, 病院患者よりバイアスの少ない一般集団をもと
にした地域がん登録統計からも明らかである(図 6) ${ }^{5}$. 近位部は, 日本人男性で 15 20\%, 女性で 10〜15\%にすぎないのに対し，欧米諸国では， 胃癌の少ない地域ではお拉よそ男性で半分以上, 女性でも 25 40\%以上が近位部から発生してい る. 欧米でも, イタリアのように比較的胃癌の 多い地域では, 他の欧米諸国と比較して遠位部 の割合が高い。また，早期胃癌や高齢者胃癌で は遠位部の割合がさらに高くなっている。

第二に，各国の胃癌 5 年相対生存率を比較し

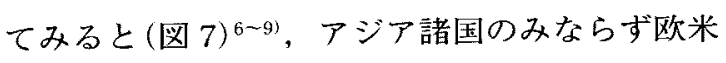
諸国でも5 年生存率は概ね $20 \%$ 程度であるが, わが国でのみ $40 \%$ を超えて扔り,他国と比較し て高い。さらに，胃癌の診断時の進展度を比較 すると，わが国の胃癌は診断時に限局している 


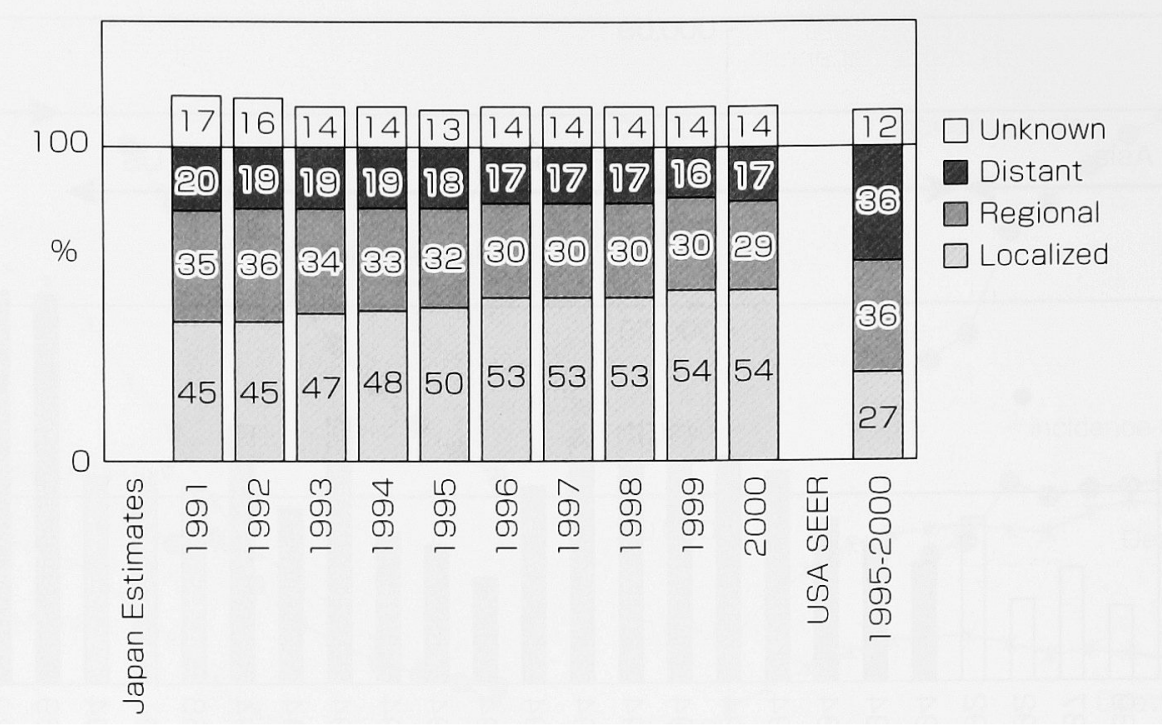

図 8. 胃癌進展度の年次推移 (文献 6,10より)

割合が $50 \%$ と高いことである ${ }^{10)}$ (図 8).これは 米国の人口の約 $10 \%$ をカバーする地域がん登録 SEERプログラムからの統計の $27 \% \%^{6)}$ とは大きく 異なっており, 他の欧米先進国も同様と推測さ れる．このことから，わが国に扝ける，他国と 比較して良好な 5 年生存率には, 限局胃癌の割 合が大きいことが寄与しているものと考えられ る.

\section{4. 胃癌の動向の背景要因}

胃癌の背景要因を考える上で重要なのが, 胃 循の地域差と, 欧米先進国における低下の背景 である。胃癌の地域差の背景には, 食生活の違 いがあると考えられている.このことは, 米国 に渡った日系移民の胃癌罹患率が減少し, 低率 な米国白人に近づいていくことなどからも裏づ

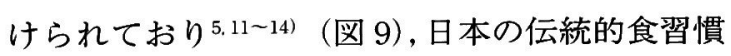
が胃癌のリスクに影響を及ぼしている可能性を 示唆している.また, 胃癌は, ほとんどの国に おいて一貫した低下傾向を示しているが，特に 低下の著しい欧米諸国では胃癌検診を行ってお らず，わが国より診断技術が優っているとも考
えにくい。このため,この低下は主に, 冷蔵・ 冷凍保存など食品貯蔵方法の改善による, 塩分 摂取の低下, 新鮮な野菜・果物搨取の増加によっ て必然的にもたらされたものと考えられている.

一方, 近年ではHelicobacter pylori (H. pylori) 感 染が胃癌の重要な要因として確実視されている. H. pylori感染には, 特に小児期における衛生環境 が重要であるが, すべての感染者が胃癌になる わけではなく, また, 同じアジア諸国において, 日本や韓国のようにH. pylori感染と胃癌がともに 高率である国がある一方で，インドやタイ，バ ングラデシュのようにH. pylori感染は高率にもか

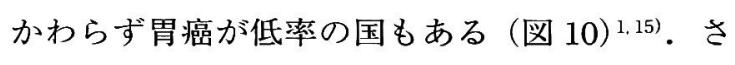
らに, H. pylori感染は従来日本人に多い遠位部の がんとの関連が強く, 欧米のように感染率の低 い場合はむしろ, 近位部のがんの割合が増加す る可能性も示唆されている. このことから, そ の発癌機序には, H. pyloriの感染の有無に加え, 宿主要因や菌自体の毒性, 食習慣をはじめとす る環境要因など様々な要因がかかわっていると 考えられ，今後の解明が期待される. 


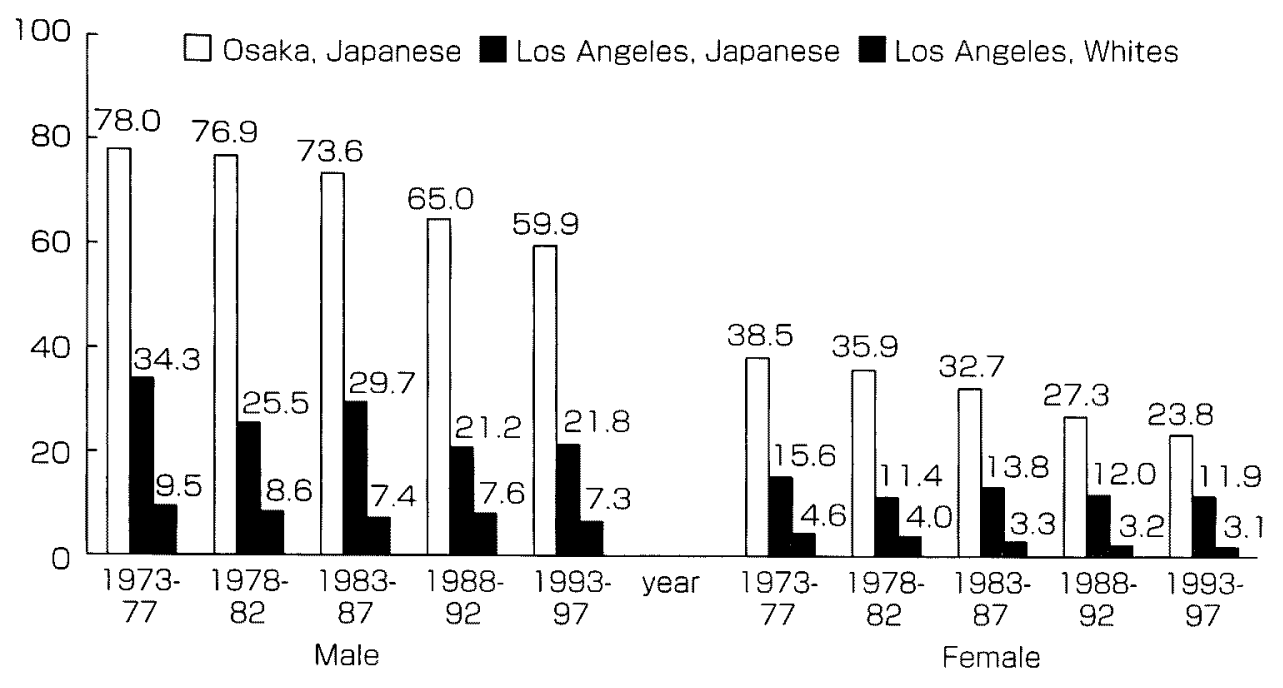

図 9. 移民の胃癌罹患（文献 $5 ， 11 \sim 14$ より）

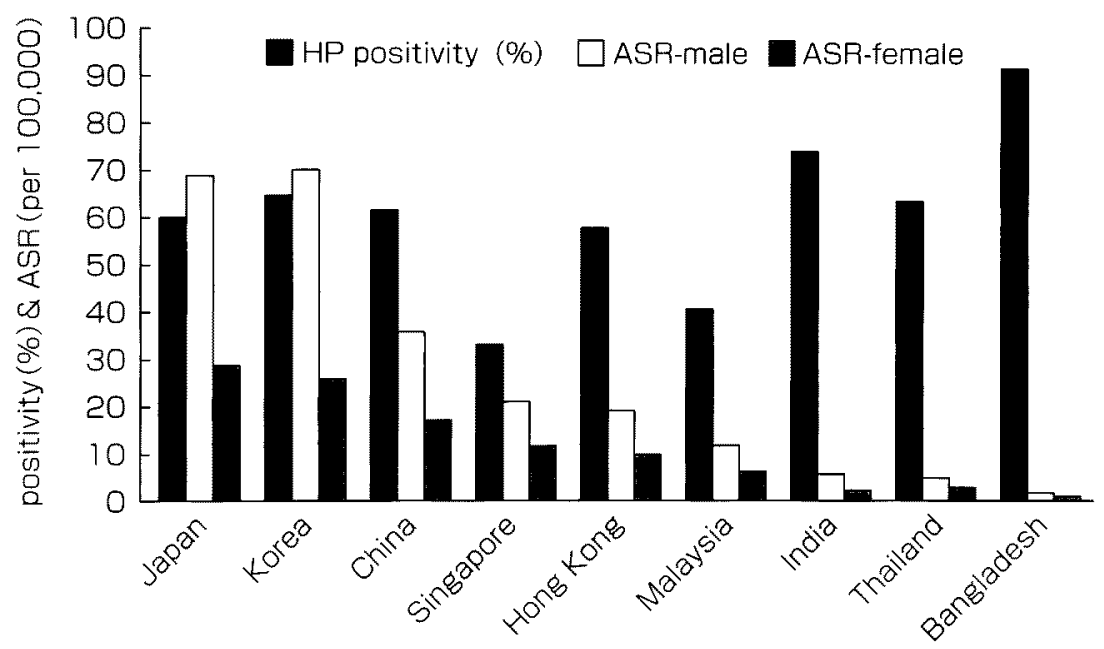

図 10. アジアにおけるHelicobacter pylori感染と胃癌篗患率の比較（文献 $1 ， 15$ より）

\section{5. 将来の胃癌の動向}

わが国における胃癌の今後の動向を, 最近の 将来推計に基づいて見てみると ${ }^{2}, 2000$ 年以降 2020 年までの 20 年間に死亡率は $40 \sim 50 \%$ ，罹 患率は 25３0\% 減少すると推測される(図 5). 一方，急速な高龄化に伴い，男女とも死亡数は 横ばい, 罹患数は徐々に増加してピークに達す
ると予測され，数そのものが低下傾向に転じる までには今しばらく時間がかかると考えられる。 わが国では，第二次世界大戦後，小児期の衛 生環境が著しく向上し，それに伴って若年層の H. pylori感染率は自然に低下していくと思われる. そのため, さらに高塩掑取の欧米諸国並みの低 下が実現されれば，わが国の胃癌は，まだな捛 主要ながんと位置づけられているものの, 他の 先進諸国と同様，長期的には大きく低下してい 
くと子想される。

\section{文献}

1) Ferlay J, et al:GLOBOCAN 2000: Cancer Incidence, Mortality and Prevalence Worldwide, Version 1.0. IARC CancerBase No.5. Lyon, IARCPress, 2001.

2）厚生労働省大臣官房統計情報部：平成 15 年人口動態統計 月報年計(概数)の概況.http://www.mhlw.go.jp/toukei/ saikin/hw/jinkou/geppo/nengai03/index.html, 2004.

3) The Research Group for Population-based Cancer Registration in Japan : Cancer incidence and incidence rates in Japan in 1999: estimates based on data from 11 population-based cancer registries. Jpn J Clin Oncol 34, 2004 in press.

4）大島 明,他編：が九・統計白書一羅患/死亡/予後—2004. 篠原出版新社, 2004.

5) Parkin DM, et al (eds) : Cancer Incidence in Five Continents, Vol. VIII, IARC Scientific Publications No. 155 , IARC, Lyon, 2002.

6) Ries LAG, et al (eds) : SEER Cancer Statistics Review, 1975-2001, National Cancer Institute. Bethesda, MD, http://seer.cancer.gov/csr/1975_2001/,2004.

7) Sankaranarayanan R, et al (eds) Cancer Survival in De- veloping Countries, IARC Scientific Publication No. 145, IARC, Lyon, 1999.

8) Sant M, et al: EUROCARE-3: survival of cancer patients diagnosed 1990-94 -results and commentary. Ann Oncol 14 Suppl 5 : v61-118, 2003.

9）味木和喜子, 他：地域がん登録における生存率計測の標 準方式の検討. がんの臨床 44:981-993, 1998.

10）厚生労倬省がん研究助成金「地域がん登録の精度向上と 活用に関する研究」班平成 6-15 年度報告萻, 1995-2004.

11) Parkin DM, et al (eds) : Cancer Incidence in Five Continents, Vol. VII, IARC Scientific Publications No. 143, IARC, Lyon, 1997.

12) Parkin DM, et al (eds) : Cancer Incidence in Five Continents, Vol. VI. IARC Scientific Publications No. 155. IARC, Lyon, 1992.

13) Muir $\mathrm{C}$, et al (eds) : Cancer Incidence in Five Continents, Vol. V. IARC Scientific Publications No. 88. IARC, Lyon, 1987.

14) Waterhouse J. DM, et al (eds) : Cancer Incidence in Five Continents, Vol. IV. IARC Scientific Publications No. 42, IARC, Lyon, 1982.

15) Miwa H, et al:H. pylori and gastric cancer: The Asian enigma. Am J Gastroenterol 97 : 1106-1112, 2002. 